\title{
Utjecaj prethodne terapije statinima na težinu kliničke slike sepse iz opće populacije
}

\author{
Marija Križić', Iva Miškulin², Marija Santini ${ }^{3,4}$, Bruno Baršici, 34 \\ ${ }^{1}$ Klinika za onkologiju, Klinički bolnički centar Zagreb, Zagreb \\ ${ }^{2}$ Klinika za ženske bolesti i porode, Klinički bolnički centar Zagreb, Zagreb \\ ${ }^{3}$ Klinika za infektivne bolesti,„Dr. Fran Mihaljević, Zagreb \\ ${ }^{4}$ Medicinski fakultet Sveučilišta u Zagrebu
}

The impact of prior statin therapy on the severity of community acquired sepsis

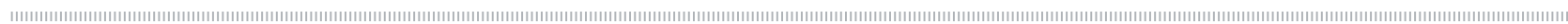

Ključne riječi:

sepsa

statini

upalniodgovor

SOFA zbroj

mortalitet

Keywords:

sepsis

statins

inflammatory response

SOFA score

mortality

Primljeno: 15-10-2019

Received: 15-10-2019

Prihvaćeno: 17-12-2019

Accepted: 17-12-2019

$\triangle$ Adresa za dopisivanje:

Marija Križić, dr. med.

Klinika za onkologiju, Klinički bolnički centar Zagreb,

Kišpatićeva 12, 10000 Zagreb

e-mail:mkrizic13@gmail.com

Sažetak

Uvod: Smrtnost sepse je visoka usprkos antimikrobnim lijekovima, stoga se ispituju imunomodulatorni lijekovi, između ostalih i statini.

Cilj: Pokazati imaju li bolesnici prethodno liječeni statinima lakši klinički oblik i manju smrtnost sepse.

Ustroj: Retrospektivno kohortno, opservacijsko istraživanje, usporedba prethodno liječenih i prethodno neliječenih statinima.

Ispitanici: Sepsa iz opće populacije, bakterijski izolat iz hemokultura, dob $\geq 50$ god.

Rezultati: Uključeno 899 bolesnika, 116 (12.9\%) prethodno liječenih statinima. Bez statistički značajnih razlika u izraženosti parametara sustavnog upalnog odgovora. Medijan SOFA zbroja u prethodno liječenih statinima iznosio je 2.0 kao i u skupini prethodno neliječenih ( $p=0.117)$. Ukupna smrtnost $9.2 \%$, prethodno liječeni $6.0 \%$, prethodno neliječeni 9.7\%, ( $p=0.231$ ). Nema razlike u 28-dnevnoj smrtnosti (log-rank test, $p=0.693$ ).

Zaključak: Nema statistički značajne razlike u težini kliničke slike kao ni u smrtnosti sepse između bolesnika prethodno liječenih i prethodno neliječenih statinima.

Abstract
Introduction: Sepsis mortality is high despite antimicrobial drugs, therefore immunomodulatory drugs (includ-
ing statins) are being investigated.
Objective: To show whether patients with prior statin therapy had less severe clinical presentation and lower
mortality of sepsis.
Design: Retrospective, cohort, observational study, comparison of patients with and without prior statin therapy.
Patients: Community-acquired sepsis, age $\geq 50$ years, bacterial isolate from blood cultures.
Results: 899 patients included, $116(12.9 \%)$ with prior statin therapy. No significant difference in SIRS param-
eters. Median SOFA score 2.0 in both groups ( $p=0.1179$ ). Total mortality $9.2 \%$, in prior statin group $6.0 \%$, in
nonprior statin group $9.7 \%$ ( $p=0.231$ ). No difference in 28 -day mortality, log-rank test, $p=0.693$ ).
Conclusion: There are no statistically significant differences in the severity and mortality of community acquired
sepsis in patients with and without prior statin therapy.
\end{abstract}

Uvod

Sepsa se definira kao sustavni upalni odgovor ljudskog organizma koji je prouzročen infekcijom koja može, ali ne mora biti dokazana. ${ }^{[1]}$ Prema podatcima iz SAD-a od sepse godišnje obolijeva oko 750000 osoba, ${ }^{[2]}$ a jedna četvrtina oboljelih razvija kliničku sliku teške sepse i septičkog šoka. Današnje smjernice za liječenje sepse temelje se na ranoj primjeni antimikrobnih lijekova te na cijelom nizu mjera koje su usmjerene na korekciju i održavanje poremećenih vitalnih funkcija. ${ }^{[3]}$ Usprkos suvremenim principima liječenja mor- talitet teške sepse i septičkog šoka iznosi 30 do 50\%. ${ }^{[4]}$ Smatra se da je jedan dio nepovoljnih ishoda posljedica pretjeranog upalnog odgovora, oslobađanja brojnih proupalnih molekula, generalizirane disfunkcije endotela krvnih žila i oštećenja funkcije organa udaljenih od primarnog sijela infekcije (tzv. multiorgansko zatajenje). Pomak u liječenju najtežih oblika infekcija stoga se očekuje od lijekova koji imaju mogućnost modulirati imunološki odgovor oboljelih tako da ga svedu na optimum. Kandidati za idealni imunomodulatorni lijek u sepsi su brojni i u njihova istraživanja do danas 
su uložena brojna sredstva, međutim niti jedan od ispitivanih spojeva do sada se nije pokazao nedvojbeno učinkovitim i zauzeo mjesto u smjernicama za liječenje teške sepse i septičkog šoka.

Tijekom posljednja dva desetljeća kao jedna od mogućnosti za imunomodulaciju u sepsi ističu se statini. Statini su inhibitori 3-hidroksi-3-metil-glutarilkoenzim-A (HMG-CoA) reduktaze, glavnog enzima u unutarstaničnoj sintezi kolesterola. ${ }^{[5]}$ Smanjenjem razine unutarstaničnog kolesterola povećava se ekspresija receptora za LDL (low-density lipoprotein), endocitoza LDL i smanjuje se serumska razina LDL. ${ }^{[6]}$ Ovim putem se smanjuje rizik za aterosklerozu te kardiovaskularni morbiditet i mortalitet. ${ }^{[7]}$ Međutim, osim ovog osnovnog djelovanja, eksperimentalni modeli su pokazali da statini imaju i druge, tzv. pleiotropne učinke, koji uključuju protuupalna, anti-oksidativna, antikoagulacijska, pa čak i antimikrobna djelovanja.

Provedeno je niz istraživanja koja su pokazala učinkovitost statina na molekularnoj razini i uglavnom na životinjskim modelima ${ }^{[8-14]}$ koja su posljedično dovela do niza opservacijskih istraživanja koja su se bavila utjecajem primjene statina na kliničku sliku i ishod liječenja sepse.

Iako su ova istraživanja po svojoj metodologiji vrlo heterogena, meta-analiza 27 opservacijskih istraživanja pokazala je protektivan utjecaj prethodne terapije statinima na težinu kliničke slike i smrtnosti od sepse. ${ }^{[15]}$ Ta pozitivna opservacijska istraživanja dovela su do velikog broja randomiziranih kliničkih istraživanja $\mathrm{u}$ posljednjem desetljeću. Međutim rezultati nekoliko meta-analiza randomiziranih kliničkih istraživanja nisu utvrdili razliku u mortalitetu između bolesnika liječenih statinima i onih koji su primali placebo. ${ }^{[16,17,18]}$

S obzirom da su rezultati opservacijskih i randomiziranih kliničkih istraživanja uglavnom oprečni i nekoherentni, i dalje se provode i jedna i druga istraživanja kako bi se došlo bliže konačnim zaključcima.

Mi smo odlučili provesti retrospektivno kohortno istraživanje o utjecaju prethodne terapije statinima na težinu kliničke slike sepse u bolesnika iz opće populacije koji su prilikom hospitalizacije imali bakterijski izolat $\mathrm{u}$ hemokulturama.

Opći cilj našeg istraživanja bio je istražiti imaju li bolesnici koji su prethodno primali statine lakšu kliničku sliku sepse od bolesnika koji prethodno nisu primali statine. Specifični ciljevi bili su istražiti utjecaj prethodne terapije statinima na: izraženost kliničkih parametara sustavnog upalnog odgovora, težinu kliničke slike sepse, tj. disfunkciju organa u sepsi izračunavanjem SOFA zbroja (Sequential Organ Failure Assesment Score), na potrebu za liječenjem u jedinici intenzivnog liječenja (JIL), na potrebu za mehaničkom ventilacijom (MV), na vitalni status na kraju liječenja u bolnici i na 28-dnevni mortalitet.

\section{Ispitanici i metode}

Radi se o retrospektivnom, opservacijskom, kohortnom istraživanju koje je obuhvatilo četverogodišnje razdoblje (od 1. siječnja 2008. do 31. prosinca 2011. god.) u Klinici za infektivne bolesti „Dr. Fran Mihaljević" Medicinskog fakulteta Sveučilišta u Zagrebu u sklopu projekta „Procjena potrebe i učinka liječenja u jedinicama intenzivne medicine". Klinika za infektivne bolesti „Dr. Fran Mihaljević” je ustanova tercijarne zdravstvene skrbi koja ima 250 kreveta, a u njoj se godišnje liječi oko 7000 hospitaliziranih.

Kriteriji za uključenje bolesnika u istraživanje bili su sljedeći: klinička slika sepse iz opće populacije prema aktualnim kriterijima za dijagnozu sepse ${ }^{1}$, bakterijski izolat iz hemokulture u prvom danu hospitalizacije, dob $\geq 50$ god.

Kriteriji za isključenje bili su: bolesnici bez kliničke slike sepse iz opće populacije i oni sa sepsom stečenom u drugoj medicinskoj ustanovi ili ustanovi za kroničnu zdravstvenu skrb, bolesnici bez izolata iz hemokultura tijekom prvog dana hospitalizacije i bolesnici u dobi $\leq$ 49 god.

Kao prediktorne varijable analizirali smo: dob, spol, zastupljenost komorbiditetnih stanja putem Charlson Comorbidity Indexa ${ }^{[19]}$, prethodno uzimanje statina (bilo koja vrsta statina).

Kao glavnu varijablu ishoda analizirali smo SOFA zbroj $^{[20]}$, koji je pokazatelj težine sepse tj. zastupljenosti disfunkcije pojedinih organa i organskih sustava u teškoj sepsi. Ovaj bodovni sustav ocjenjuje sljedeće: funkciju kardiovaskularnog sustava (srednji arterijski tlak i potrebu za primjenom vazoaktivnih lijekova), funkciju koagulacijskog sustava (broj trombocita), funkciju jetre (vrijednost bilirubina), stanje svijesti izraženo putem Glasgow ComaScore (GCS) ${ }^{[21]}$, renalnu funkciju (vrijednost kreatinina) te respiratornu funkciju na temelju omjera parcijalnog tlaka kisika u arterijskoj krvi i frakcije kisika u udahnutom zraku $\left(\mathrm{PaO}_{2} / \mathrm{FiO}_{2}\right.$ omjer $)$.

Ostale varijable ishoda bile su: izraženost kliničkih parametara sustavnog upalnog odgovora (tahikardija - broj otkucaja srca $>90 / \mathrm{min}$., tjelesna temperatura $<36^{\circ} \mathrm{C}$ ili $>38^{\circ} \mathrm{C}$, tahipneja - broj udisaja $>20 / \mathrm{min}$. ili parcijalni tlak $\mathrm{CO}_{2}$ u krvi $<4.3 \mathrm{kPa}(32 \mathrm{~mm} \mathrm{Hg})$ i broj leukocita $<4000 / \mathrm{mm}^{3}$ ili $>12000 / \mathrm{mm}^{3}$ ili prisutnost više od $10 \%$ nezrelih neutrofilnih stanica) ${ }^{[22]}$, potreba za liječenjem u JIL, potreba za MV, potreba za primjenom vazopresornih lijekova, vitalni status kod završetka hospitalizacije i 28-dnevno preživljenje.

Podatci su prikupljani retrospektivno iz povijesti bolesti putem strukturiranog formulara i odmah uno- 
šeni u bazu podataka u računalnom programu Microsoft Access

Statistička analiza provedena je uporabom statističkog software-a SAS, verzija 9.2. Rezultati u analizi za kontinuirane varijable izraženi su kao prosjek \pm standardna devijacija (SD), medijan i interkvartilni raspon (25.-75. percentila), a kategoričke varijable kao frekvencije i postotci. Kategorijske varijable uspoređene su hi-kvadrat ili Fisherovim egzaktnim testom. Kontinuirane varijable uspoređene su t-testom ili analizom varijance (ukoliko su zadovoljeni uvjeti normalne distribucije i homogenosti varijanci). U slučaju nezadovoljenja uvjeta primijenjeni su neparametrijski testovi. Ishodna varijabla 28-dnevne smrtnosti analizirana je Kaplan-Meierovom krivuljom preživljenja. Razlike su ispitane log-rank testom. Nul-hipoteza je odbačena ukoliko je p-vrijednost u navedenim testovima $<0.05$.

\section{Rezultati}

Kriterije za uključenje u istraživanje zadovoljilo je ukupno 899 bolesnika, srednje dobi $72 \pm 11$ godina, od kojih su 520 (57.8\%) bile žene, sa srednjom vrijednosti Charlson scorea $6 \pm 3$, medijan 6 , interkvartilni raspon (IKR) 4-7. Bolesnici prethodno liječeni statinima činili su 116 (12.9\%) uključenih, srednje dobi $72 \pm 9$ god, a 65 (56.0\%) bolesnika su predstavljale žene, srednji Charlson score $6 \pm 2$, medijan 6 , IKR 4-7.

Skupinu bolesnika prethodno neliječenih statinima predstavljalo je 783 (87.1\%) uključenih, srednje dobi $72 \pm 11$ godina, $455(58,1 \%)$ žena, srednji Charlson score $6 \pm 3$, medijan 6 , IKR 4-7. Svi navedeni podaci pregledno su prikazani u Tablici 1. Nije bilo statistički značajne razlike među ispitanim skupinama prema dobi, spolu i prethodnim komorbiditetima.

TABLICA 1. OSNOVNE KARAKTERISTIKE I USPOREDBA SKUPINA PRETHODNO LIJEČENIH I PRETHODNO NELIJEČENIH STATINIMA

TABLE 1. BASELINE CHARACTERISTICS AND COMPARISON OF GROUPS WITH AND WITHOUT PRIOR STATIN THERAPY

\begin{tabular}{|l|l|l|l|l|}
\hline & $\begin{array}{l}\text { Prethodno neliječeni } \\
\text { statinima } \\
(\mathbf{N}=\mathbf{7 8 3})\end{array}$ & $\begin{array}{l}\text { Prethodno liječeni } \\
\text { statinima } \\
(\mathbf{N = 1 1 6 )}\end{array}$ & $\begin{array}{l}\text { Ukupno } \\
(\mathbf{N}=899)\end{array}$ & P-vrijednost \\
\hline Dob (godine) & $72 \pm 11$ & $72 \pm 9$ & $72 \pm 10$ & 0.6250 \\
\hline Srednja vrijednost \pm SD & $73(63-81)$ & $72(66-79)$ & $73(64-80)$ & 0.6878 \\
\hline Medijan (raspon) & & & & \\
\hline Spol & $455(58.1 \%)$ & $65(56.0 \%)$ & $320(57.8 \%)$ & \\
\hline Žene (\%) & $328(41.9 \%)$ & $51(44.0 \%)$ & $379(42.2 \%)$ & 0.7857 \\
\hline Muškarci (\%) & & & $3 \pm 3$ & \\
\hline Charlson score & $6 \pm 3$ & $6 \pm 2$ & $6(4-7)$ & \\
\hline Srednja vrijednost \pm SD & $6(4-7)$ & $6(4-7)$ & & \\
\hline Medijan (raspon) & & & \\
\hline
\end{tabular}

Zastupljenost pojedinih ishodišta sepse prikazana je grafički za sve uključene te za podgrupe prethodno neliječenih i prethodno liječenih statinima na Slici 1. Kao što je vidljivo u cijeloj kohorti najzastupljenije su bile infekcije mokraćnog sustava (61.0\%), infekcije kože i potkožnog tkiva (13.1\%) te infekcije s ishodištem u abdomenu (10.8\%). Najzastupljenija ishodišta u skupini prethodno neliječenih statinima su bila: mokraćni sustav (60.5\%), koža i potkožno tkivo (14.2\%) i abdomen (10.1\%). Među bolesnicima prethodno liječenim statinima najzastupljenija su bila ishodišta: mokraćni sustav (63.8\%), abdomen (15.5\%) te koža i potkožno tkivo (6.0\%) jednako kao i ostala ishodišta (6.0\%). Dakle, bolesnici prethodno liječeni statinima su imali veću zastupljenost intraabdominalnih infekcija, dok su bolesnici prethodno neliječeni statinima imali veću zastupljenost infekcija kože i potkožnog tkiva. Ispitivane skupine su se statistički razlikovale prema zastupljenosti pojedinih ishodišta sepse $(\mathrm{p}=0.0474)$.

Zastupljenost pojedinih uzročnika grafički je prikazana na Slici 2. Među uzročnicima u svih uključenih bolesnika najzastupljenije su bile enterobakterije (69.7\%), potom stafilokoki (9.2\%) i beta-hemolitički streptokoki (6.2\%). Kod bolesnika prethodno liječenih statinima najzastupljenije su bile enterobakterije (73.3\%), stafilokoki (9.5\%) i beta-hemolitički streptokoki (4.3\%). Među bolesnicima prethodno neliječenim statinima raspored uzročnika je bio isti, ali s različitim udjelima: enterobakterije (69.2\%), stafilokoki (9.2\%) i beta-hemolitički streptokoki (6.5\%). Nije pronađena statistički značajna razlika u zastupljenosti pojedinih uzročnika $\mathrm{u}$ ispitivanim skupinama bolesnika ( $\mathrm{p}=$ 0.7496). 
SLIKA 1. ZASTUPLJENOST PRIMARNIH ISHODIŠTA INFEKCIJE U BOLESNIKA PRETHODNO NELIJEČENIH STATINIMA, PRETHODNO LIJEČENIH STATINIMA I U UKUPNOJ POPULACIJI BOLESNIKA

Figure 1. REPRESENTATION OF PRIMARY SOURCES OF INFECTION AMONG NON-STATIN, STATIN USERS AND TOTAL STUDY POPULATION

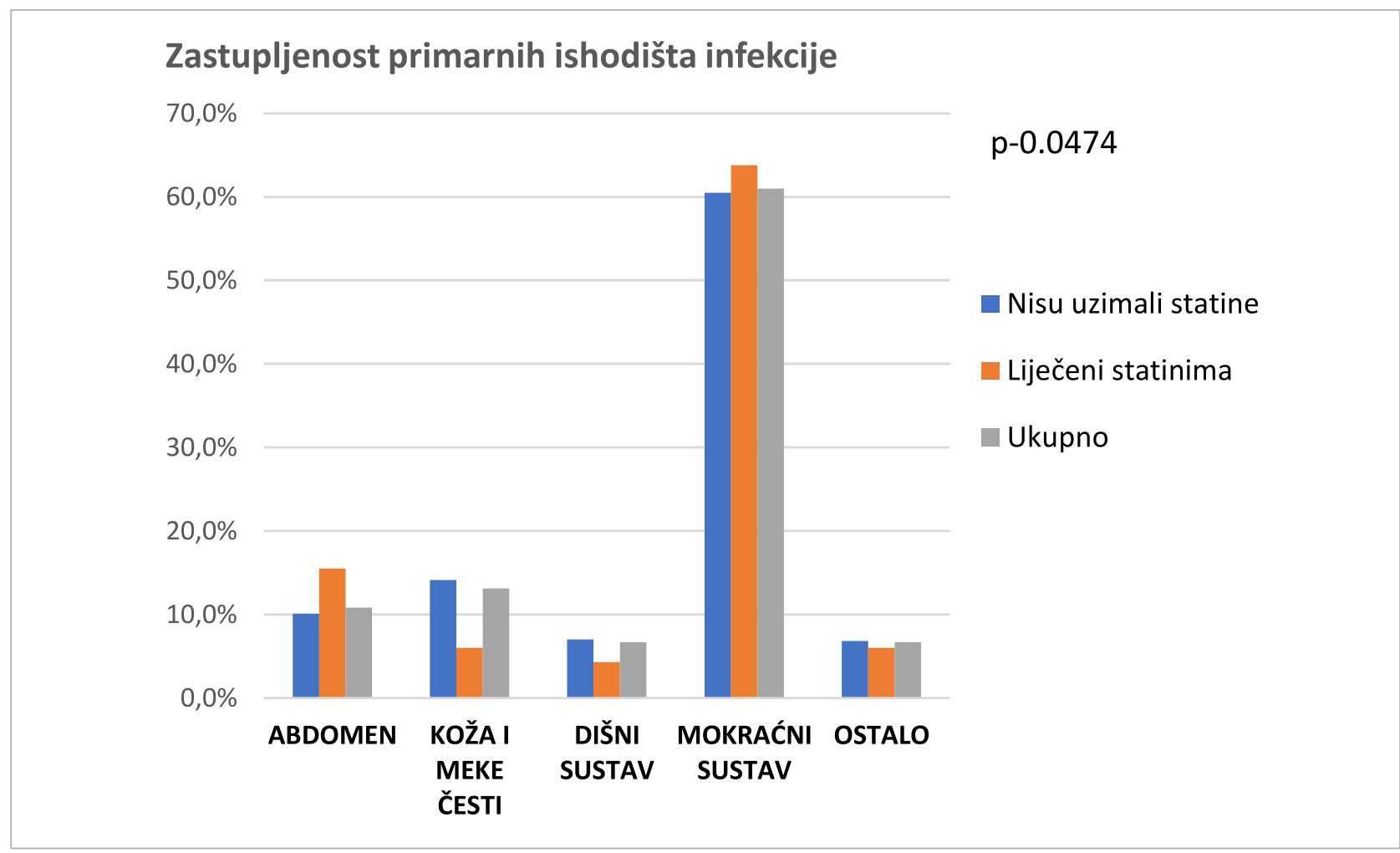

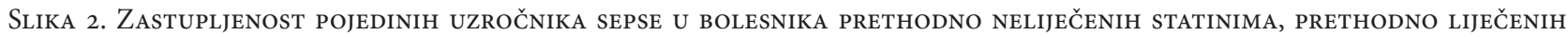
STATINIMA I U CJELOKUPNOJ POPULACIJI BOLESNIKA

FigURE 2. REPRESENTATION OF PARTICULAR PATHOGENS IN SEPSIS AMONG NON-STATIN USERS, STATIN USERS AND TOTAL STUDY POPULATION

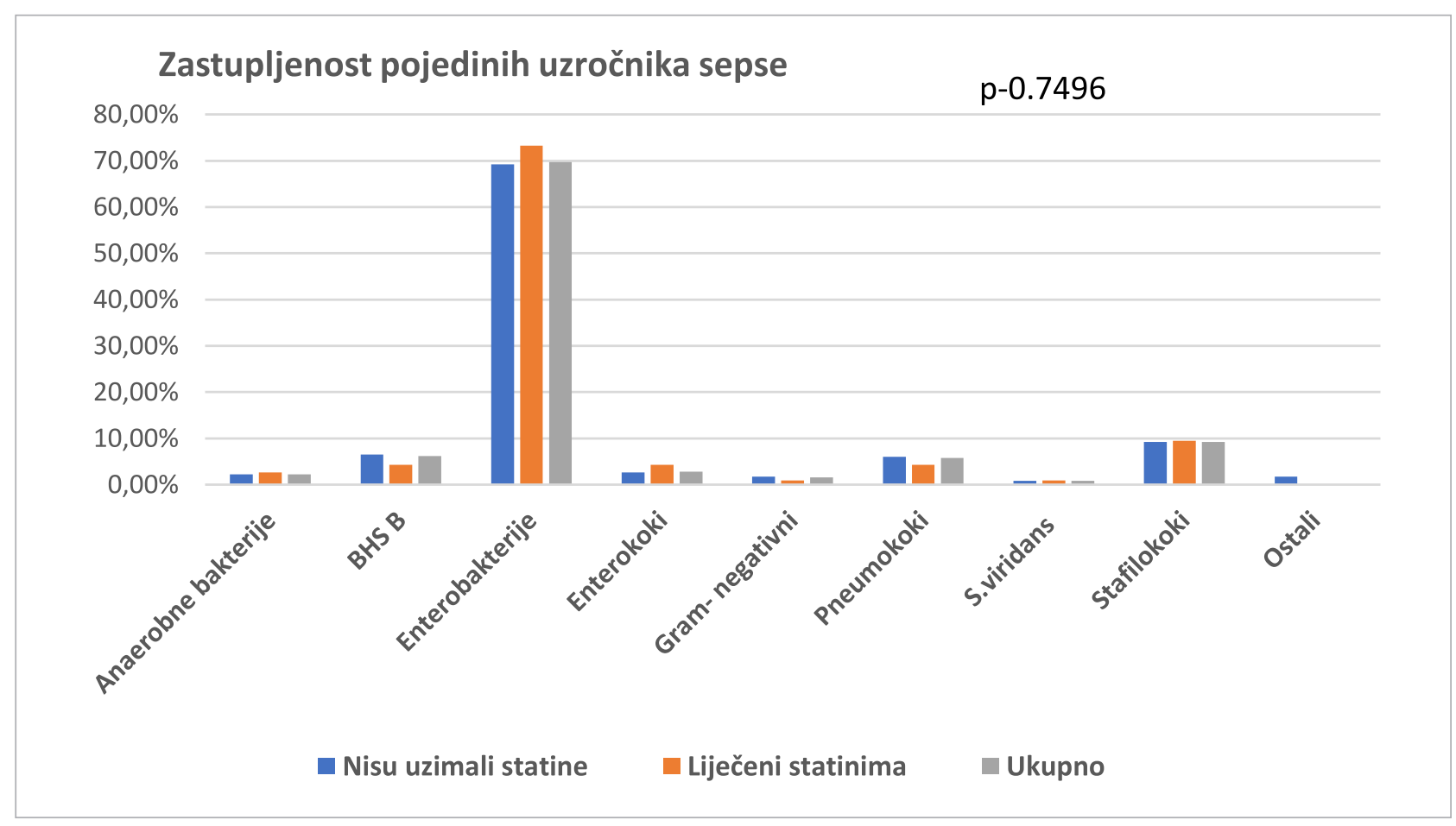


Usporedba prethodno neliječenih i prethodno liječenih statinima prema izraženosti parametara sustavnog upalnog odgovora prikazana je u Tablici 2. Nema statistički značajne razlike u vrijednostima parametara sustavnog upalnog odgovora u skupini bolesnika liječenih statinima i u skupini neliječenih.

TABLICA 2. USPOREDBA PRETHODNO NELIJEČENIH I PRETHODNO LIJEČENIH STATINIMA PREMA IZRAŽENOSTI PARAMETARA SUSTAVNOG UPALNOG ODGOVORA

TAble 2. Comparison betWeen NON-STAtin ANd Statin group Defined by SIRS (Systemic Inflammatory Response Syndrome) CRITERIA

\begin{tabular}{|c|c|c|c|c|}
\hline & $\begin{array}{l}\text { Prethodno neliječeni } \\
\text { statinima } \\
(\mathrm{N}=783)\end{array}$ & $\begin{array}{l}\text { Prethodno liječeni } \\
\text { statinima } \\
(\mathrm{N}=116)\end{array}$ & $\begin{array}{l}\text { Ukupno } \\
(\mathrm{N}=899)\end{array}$ & $\mathrm{p}$ \\
\hline $\begin{array}{l}\text { Respiratorna frekvencija } \\
\text { (broj respiracija/min.) }\end{array}$ & & & & 0.3242 \\
\hline Srednja vrijednost \pm SD & $21.5 \pm 6.5$ & $20.7 \pm 5.6$ & $21.4 \pm 6.4$ & \\
\hline Medijan & $20(16-24)$ & $20(16-22)$ & $20(16-24)$ & \\
\hline \multirow[t]{2}{*}{ Prisutnost tahipneje (>20/min.) } & & & & 0.5467 \\
\hline & $451(57.6 \%)$ & $63(54.3 \%)$ & $63(54.3 \%)$ & \\
\hline Srčana frekvencija (broj otkucaja/min). & & & & 0.4948 \\
\hline Srednja vrijednost \pm SD & $94.0 \pm 19.3$ & $92.4 \pm 20.6$ & $93.8 \pm 19.4$ & \\
\hline Medijan & $90(80-104)$ & $90(80-100)$ & $90(80-104)$ & \\
\hline \multirow[t]{2}{*}{ Prisutnost tahikardije (>90/min.) } & & & & 0.8414 \\
\hline & $349(44.6 \%)$ & $50(43.1 \%)$ & $399(44.4 \%)$ & \\
\hline Tjelesna temperatura $\left({ }^{\circ} \mathrm{C}\right)$ & & & & 0.7021 \\
\hline Srednja vrijednost \pm SD & $38.2 \pm 1.2$ & $38.3 \pm 1.2$ & $38.2 \pm 1.2$ & \\
\hline Medijan (raspon) & $38.0(37.0-39.0)$ & $38.0(37.0-39.0)$ & $38.0(37.0-39.0)$ & \\
\hline \multirow[t]{2}{*}{$\begin{array}{l}\text { Prisutnost febriliteta }\left(>38^{\circ} \mathrm{C}\right) \text { ili } \\
\text { hipotermije }\left(<36^{\circ} \mathrm{C}\right)\end{array}$} & & & & 0.6383 \\
\hline & $603(77.0 \%)$ & $87(75.0 \%)$ & $690(76.8 \%)$ & \\
\hline Broj leukocita $\left(\times 10^{9} / \mathrm{L}\right)$ & & & & 0.7862 \\
\hline Srednja vrijednost & \pm SD $14.9 \pm 7.5$ & $14.6 \pm 6.6$ & $14.8 \pm 7.4$ & \\
\hline Medijan & 14.0 & 14.0 & 14.0 & \\
\hline
\end{tabular}

Na Slici 3. grafički je prikazana distribucija SOFA zbroja za cijelu ispitivanu kohortu te usporedba dvaju ispitivanih skupina. Prosječna vrijednost SOFA zbroja u ukupnoj populaciji bolesnika bila je 3.1 \pm 3.1 , u skupini liječenih statinima $2.7 \pm 2.8$, a u skupini neliječe-

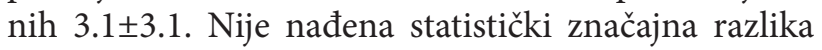
u SOFA zbroju između skupine prethodno liječenih i skupine prethodno neliječenih statinima, $\mathrm{p}=0.1633$.

Analiza ostalih varijabli koje indirektno pokazuju težinu bolesti (potreba za hospitalizacijom u JIL-u, potreba za MV, potreba za primanjem vazoaktivnih lijekova te vitalni status kod završetka liječenja u bolnici) prikazana je u Tablici 3. Od ukupno 899 uključenih bolesnika 125 (13.9\%) bolesnika su liječeni u JIL, 106 (11.8\%) su mehanički ventilirani, 47 (5.2\%) su primali vazoaktivne lijekove. Bolesnici prethodno liječeni statinima su imali minimalno veću zastupljenost liječenih u JIL (14.7 vs. 13.8\%), mehanički ventiliranih (13.8 vs. $11.5 \%)$ te jednak udio bolesnika liječenih vazopresorima (5.2\%). Kao što je vidljivo u tablici ove razlike se nisu pokazale statistički značajnima.

Ukupna smrtnost cijele kohorte iznosila je 83 (9.2\%) bolesnika i bila je nešto veća u skupini prethodno liječenih statinima, $94.0 \%$ vs. $90.0 \%, p=0.2321$, što nije statistički značajna razlika. 
SLIKA 3. GRAFIČKA USPOREDBA SOFA ZBROJA IZMEĐU BOLESNIKA PRETHODNO NELIJEČENIH I PRETHODNO LIJEČENIH STATINIMA Figure 3. Graphic COMPARISON OF SOFA SCORE BETWEEN NON-STATIN AND STATIN USERS

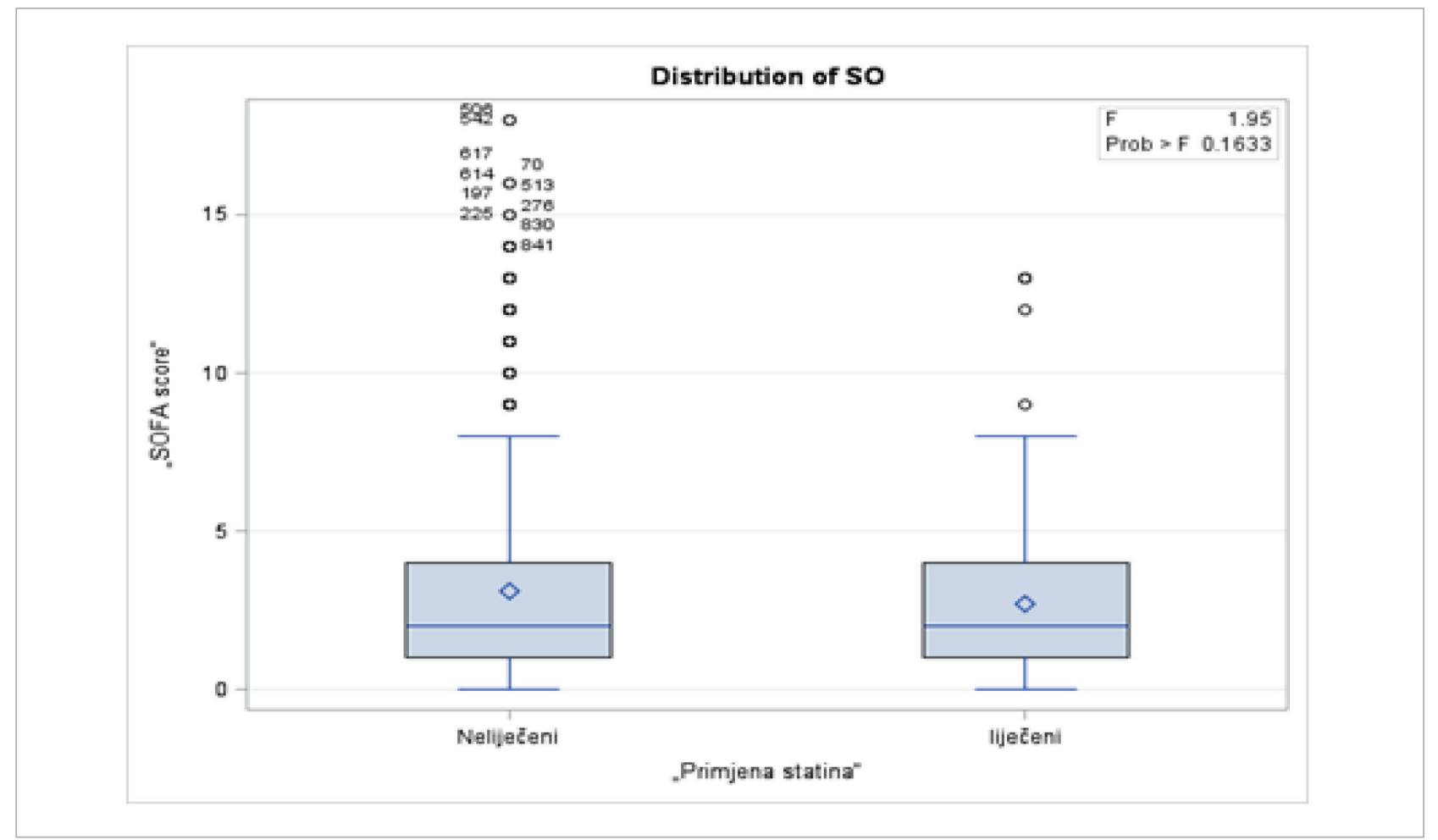

TABLICA 3. UsPoREdBA BOLESNIKA PRETHODNO NELIJEČENIH STATINIMA I PRETHODNO LIJEČENIH STATINIMA PREMA POTREBI ZA LIJEČENJEM U JIL, POTREBI ZA MEHANIČKOM VENTILACIJOM (MV), POTREBOM ZA PRIMJENOM VAZOAKTIVNIH LIJEKOVA TE PREMA VITALNOM STATUSU KOD ZAVRŠETKA LIJEČENJA U BOLNICI

TABle 3. COMPARISON BETWEEN NON-STATIN USERS AND STATIN USERS DEFINED BY THE NEED FOR ICU TREATMENT, NEED FOR MECHANiCAL VENTILATION (MV), NEED FOR VASOPRESSORS (VP) AND MORTALITY AT THE END OF HOSPITALIZATION.

\begin{tabular}{|c|c|c|c|c|}
\hline & $\begin{array}{l}\text { Prethodno neliječeni } \\
\text { statinima }\end{array}$ & $\begin{array}{l}\text { Prethodno liječeni } \\
\text { statinima }\end{array}$ & Ukupno & $\mathbf{P}$ \\
\hline Potreba za liječenjem u JIL & & & & 0.7747 \\
\hline $\mathrm{Ne}$ & $675(86.2 \%)$ & $99(85.3 \%)$ & \multicolumn{2}{|l|}{$774(86.15)$} \\
\hline $\mathrm{Da}$ & $108(13.8 \%)$ & $17(14.7 \%)$ & \multicolumn{2}{|l|}{$125(13.9 \%)$} \\
\hline Potreba za mehaničkom ventilacijom & & & & 0.448 \\
\hline $\mathrm{Ne}$ & $693(88.5 \%)$ & $100(86.2 \%)$ & \multicolumn{2}{|l|}{$793(88.2 \%)$} \\
\hline $\mathrm{Da}$ & $90(11.5 \%)$ & $16(13.8 \%)$ & \multicolumn{2}{|l|}{$106(11.8 \%)$} \\
\hline $\begin{array}{l}\text { Potreba za primjenom } \\
\text { vazoaktivnih lijekova }\end{array}$ & & & & 1.00 \\
\hline $\mathrm{Ne}$ & $742(94.8 \%)$ & $110(94.8 \%)$ & \multicolumn{2}{|l|}{$852(94.8 \%)$} \\
\hline $\mathrm{Da}$ & $41(5.2 \%)$ & $6(5.2 \%)$ & \multicolumn{2}{|l|}{$47(5.2 \%)$} \\
\hline $\begin{array}{l}\text { Vitalni status na završetku } \\
\text { hospitalnog liječenja }\end{array}$ & & & & 0.232 \\
\hline Umrli & $76(9.7 \%)$ & $7(6.0 \%)$ & \multicolumn{2}{|l|}{$83(9.2 \%)$} \\
\hline Preživjeli & $705(90.0 \%)$ & $109(94.0 \%)$ & \multicolumn{2}{|l|}{$814(90.5 \%)$} \\
\hline
\end{tabular}

Analiza 28-dnevnog preživljenja za bolesnike sa sepsom prethodno neliječene i prethodno liječene statinima prikazuje Slika 4. Kao što je vidljivo nije bilo statistički značajne razlike u 28-dnevnom preživljenju za bolesnike prethodno liječene i prethodno neliječene statinima $(\mathrm{p}=0.693)$ 
SLIKA 4. ANALIZA PREŽIVlJENJA TIJEKOM 28 DANA U BOLNiCi ZA BOLESNIKE SA SEPSOM PRETHODNO NELIJEČENE I PRETHODNO LIJEČENE STATINIMA

Figure 4. ANALYSis of THE 28-DAY MORTALity BETWEEN NON-STATIN AND STATIN USERS AMONG PATIENTS With SEPSiS

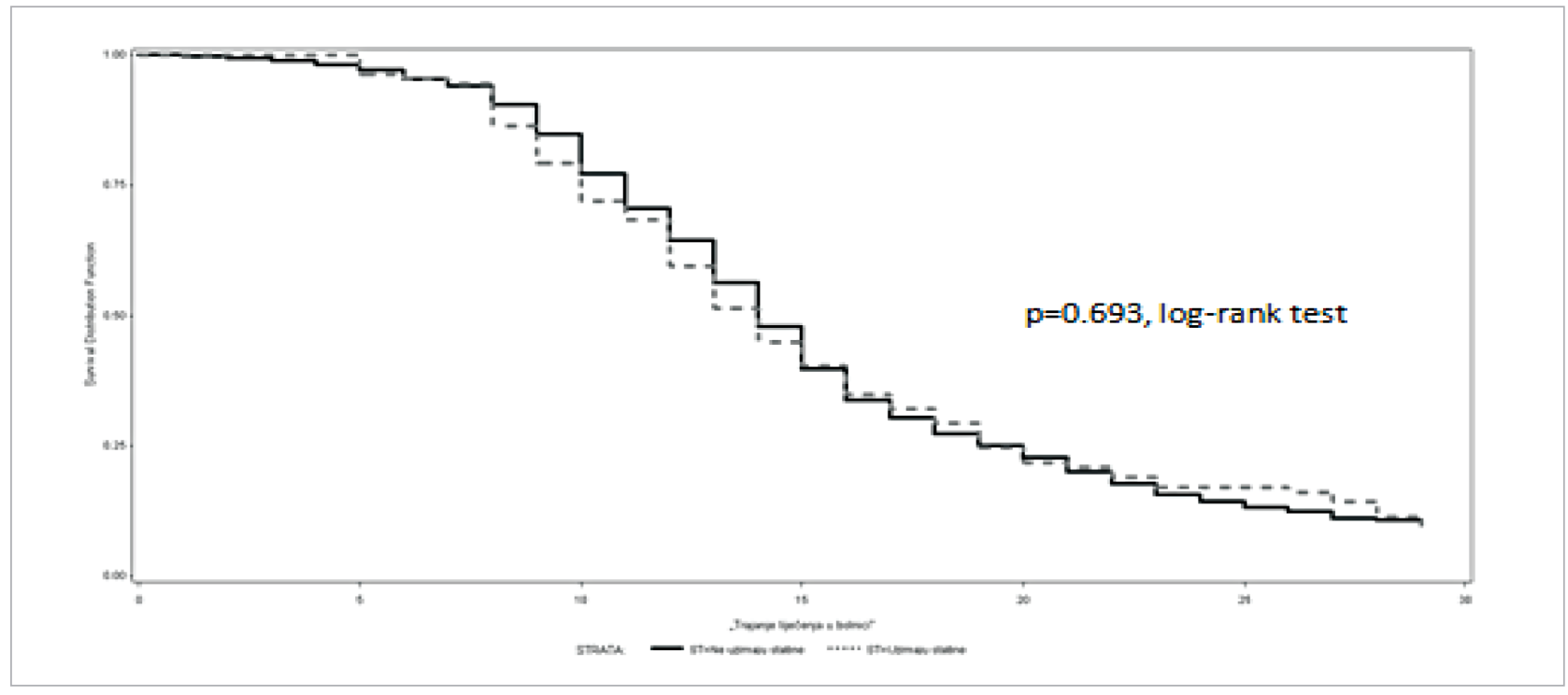

\section{Rasprava}

Glavni nalaz ovog istraživanja jest da nema statistički značajne razlike u težini kliničke slike sepse između bolesnika koji su prethodno uzimali statine za primarnu ili sekundarnu prevenciju kardiovaskularnih incidenata i onih koji nisu. Navedeno se pokazalo usporedbom izraženosti osnovnih kliničkih pokazatelja upale tj. kliničkih znakova sustavnog upalnog odgovora, težine kliničke slike sepse putem SOFA zbroja te usporedbom neizravnih pokazatelja težine bolesti (potreba za liječenjem u JIL, potreba za primjenom MV, potreba za primjenom vazoaktivnih lijekova). Osim nepostojanja statistički značajne razlike u težini kliničke slike sepse pokazalo se da prethodna terapija statinima ne utječe niti na smrtnost (usporedba vitalnog statusa na kraju liječenja i analiza 28-dnevnog preživljenja).

Unatrag dva desetljeća do danas objavljeno je nekoliko desetaka istraživanja koja su se bavila utjecajem terapije statinima na ishod liječenja sepse. Ova su istraživanja metodološki vrlo heterogena glede ustroja (retrospektivne, prospektivne, randomizirane kliničke studije), broja ispitanika, promatranja prehospitalne ili nastavljene intrahospitalne terapije statinima tijekom liječenja infekcije te prema promatranim ishodima (progresija u teži oblik sepse, broj dana bez razvoja multiorganske disfunkcije, opći mortalitet, kratkoročni ili dugoročni mortalitet). Zbog toga su usporedba rezultata i donošenje suda o postojanju ili nepostojanju pozitivnog učinka statina vrlo otežani.

Zaključivanje o utjecaju statina na smrtnost sepse ograničeno je i činjenicom da je vrlo teško razlučiti protektivni učinak statina koji proizlazi iz prevencije kardiovaskularnih incidenata tijekom sepse od protektivnog učinka koji nastaje zbog imunomodulacije. Stoga se utjecaj često površno promatra samo kao pozitivan ili negativan.

Vrlo značajnim se doima podatak da niti jedno od navedenih istraživanja koliko je nama poznato ne govori u prilog štetnom utjecaju prethodnog ili nastavljenog davanja statina u sepsi budući da se često postavljalo pitanje opisanih ozbiljnih neželjenih učinaka statina (rabdomioliza i neurotoksičnost).

Naše istraživanje ima nekoliko ograničenja. Prvo, radi se o retrospektivnom opservacijskom istraživanju u kojem su podatci prikupljani iz povijesti bolesti te je bilo nemoguće ispitati trajanje i pridržavanje prethodne terapije statinima. Stoga je na osnovu postojanja podatka o uzimanju statina u rubrici o terapiji kroničnih bolesti donesena nužna pretpostavka da je bolesnik uistinu uzimao statin. Osim toga, promatrani su klinički parametri upalnog odgovora i parametri disfunkcije organa izraženi putem SOFA bodovnog sustava samo tijekom prvog dana liječenja zato što su nam za većinu uključenih bolesnika laboratorijski nalazi potrebni za izračunavanje SOFA zbroja bili retrospektivno dostupni samo za prvi dan hospitalizacije. Stoga nam nedostaje objektivno praćenje SOFA bodovnog sustava u smislu pogoršanja ili poboljšanja tijekom liječenja. Ipak, kao surogatni parametar za najteže bolesnike, kod kojih je došlo do ozbiljne progresije bolesti, imamo podatak o primitku u JIL te primjeni mjera intenzivnog liječenja. Nismo analizirali učinak eventualnog započinjanja antimikrobne terapije prije 
hospitalizacije kao ni adekvatnost antimikrobne terapije i drugih mjera liječenja primijenjenih u bolnici što znatno može utjecati na smrtnost.

Ipak, ovo istraživanje ima i značajne kvalitete. Radi se o istraživanju koje je obuhvatilo dug, četverogodišnji vremenski period i razmjerno velik broj bolesnika s kliničkom slikom sepse i nedvojbenim izolatom signifikantnog bakterijskog uzročnika u hemokulturama. Dakle, radi se o jednom od brojčano najvećih opservacijskih kliničkih istraživanja utjecaja statina na kliničku sliku i ishod liječenja sepse s dokazanim uzročnikom dok su druga istraživanja uključivala i bolesnike samo s predmnijevanom infekcijom, bez mikrobiološkog dokaza. Osim toga, ovo istraživanje je jedino u kojem je kriterij uključenja sepsa iz opće populacije, a pritom su isključeni svi bolesnici s nozokomijalnim infekcijama i drugim rizičnim čimbenicima za promijenjen upalni odgovor i smrtni ishod.

\section{Zaključci}

Zaključno se može reći da prethodna terapija statinima ne utječe značajno na težinu kliničke slike sepse iz opće populacije, na potrebu za mjerama intenzivnog liječenja, kao ni na smrtnost sepse. Stoga, statini vjerojatno nemaju preventivni učinak u smislu modulacije upalnog odgovora na početku sepse te vjerojatno ne možemo očekivati da će bolesnici koji uzimaju statine s ciljem primarne ili sekundarne prevencije kardiovaskularnih incidenata imati lakši oblik bakterijske infekcije.

\section{LITERATURA}

${ }^{[1]}$ Levy MM, Fink MP, Marshall JC, et al. 2001 SCCM/ESICM/ ACCP/ATS/SIS International Sepsis Definitions Conference. Intensive Care Med 2003;29(4):530-8.

${ }^{[2]}$ Martin GS, Mannino DM, Eaton S, Moss M. The epidemiology of sepsis in the United States from 1979 through 2000. N Engl J Med 2003;348(16):1546-54.

${ }^{[3]}$ Bugano DD, Camargo LF, Bastos JF, Silva E. Antibiotic management of sepsis: current concepts. Expert Opin Pharmacother 2008;9(16):2817-2828.

${ }^{[4]}$ Alberti C, Brun-Buisson C, Chevret S, et al. Systemic inflammatory response and progression to severe sepsis in critically ill infected patients. Am J Respir Crit Care Med 2005;171(5):461468.

${ }^{[5]}$ Istvan ES, Deisenhofer J. Structural mechanism for statin inhibition of HMG-CoA reductase. Science 2001;292(5519):11601164.

${ }^{[6]}$ Ness GC, Holland RC, Lopez D. Selective compensatory induction of hepatic HMG-CoA reductase in response to inhibition of cholesterol absorption. Exp Biol Med (Maywood) 2006;231(5):559-565.

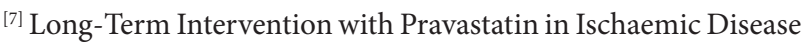
(LIPID) Study Group. Prevention of cardiovascular events and death with pravastatin in patients with coronary heart disease and a broad range of initial cholesterol levels. N Engl J Med 1998;339(19):1349-1357.

${ }^{[8]}$ Shyamsundar M, McKeown ST, O’Kane CM, et al. Simvastatin decreases lipopolysaccharide-induced pulmonary inflammation in healthy volunteers. Am J Respir Crit Care Med 2009;179(12):1107-1114.

${ }^{[9]}$ Frey T, De Maio A. Increased expression of CD14 in macrophages after inhibition of the cholesterol biosynthetic pathway by lovastatin. Mol Med. 2007;13(11-12):592-604.

${ }^{[10]}$ Durant R, Klouche K, Delbosc S, et al. Superoxide anion overproduction in sepsis: effects of vitamin e and simvastatin. Shock 2004;22(1):34-39.

${ }^{[11]}$ Bellosta S, Via D, Canavesi M, et al. HMG-CoA reductase inhibitors reduce MMP-9 secretion by macrophages. Arterioscler Thromb Vasc Biol 1998;18(11):1671-1678.

${ }^{[12]}$ Notarbartolo A, Davì G, Averna M, et al. Inhibition of thromboxane biosynthesis and platelet function by simvastatin in type IIa hypercholesterolemia. Arterioscler Thromb Vasc Biol. 1995;15(2):247-251.

${ }^{[13]}$ Jacobson JR, Barnard JW, Grigoryev DN, Ma SF, Tuder RM, Garcia JG. Simvastatin attenuates vascular leak and inflammation in murine inflammatory lung injury. Am J Physiol Lung Cell Mol Physiol 2005;288(6):L1026-L1032.

${ }^{[14]}$ Jerwood S, Cohen J. Unexpected antimicrobial effect of statins. J Antimicrob Chemother 2008;61(2):362-364.

${ }^{[15]}$ Wan YD, Sun TW, Kan QC, Guan FX, Zhang SG. Effect of statin therapy on mortality from infection and sepsis: a meta-analysis of randomized and observational studies. Crit Care 2014;18(2):R71.

${ }^{[16]}$ Pertzov B, Eliakim-Raz N, Atamna H, Trestioreanu AZ, Yahav D, Leibovici L. Hydroxymethylglutaryl-CoA reductase inhibitors (statins) for the treatment of sepsis in adults-Authors' reply. Clin Microbiol Infect 2019;25(12):1572-1573.

${ }^{[17]}$ Chen M, Ji M, Si X. The effects of statin therapy on mortality in patients with sepsis: A meta-analysis of randomized trials. Medicine (Baltimore) 2018;97(31):e11578.

${ }^{[18]}$ Deshpande A, Pasupuleti V, Rothberg MB. Statin therapy and mortality from sepsis: a meta-analysis of randomized trials. Am J Med 2015;128(4):410-7.e1.

${ }^{[19]}$ Charlson ME, Pompei P, Ales KL, MacKenzie CR. A new method of classifying prognostic comorbidity in longitudinal studies: development and validation. J Chronic Dis 1987;40(5):373-383.

${ }^{[20]}$ Vincent JL, Moreno R, Takala J, et al. The SOFA (Sepsis-related Organ Failure Assessment) score to describe organ dysfunction/failure. On behalf of the Working Group on Sepsis-Related Problems of the European Society of Intensive Care Medicine. Intensive Care Med 1996;22(7):707-710.

${ }^{[21]}$ Teasdale G, Jennett B. Assessment of coma and impaired consciousness. A practical scale. Lancet 1974;2(7872):81-84.

${ }^{[22]}$ American College of Chest Physicians/Society of Critical Care Medicine Consensus Conference: definitions for sepsis and organ failure and guidelines for the use of innovative therapies in sepsis. Crit Care Med 1992;20(6):864-874. 